\title{
Кларитроміцин - надійний антибактеріальний захист, випробуваний часом
}

У статті розглянуто загальну характеристику групи антибактеріальних препаратів, які належать до макролідів. Визначено переваги та особливості клінічного застосування кларитроміцину та його роль у лікуванні пацієнтів із легеневою та ЛОР-патологією, досягненні ерадикації при інфікуванні Helicobacter pylori, вентиляторасоційованій, нозокомінальній та позагоспітальній пневмонії, а також при септичних станах. Проаналізовано доцільність застосування форми препарату для парентерального введення у лікуванні пацієнтів із тяжкою інфекцією дихальних шляхів.

Ключові слова: пневмонія, макроліди, кларитроміцин, Helicobacter pylori, ерадикація.

\section{Загальна характеристика макролідів}

Антибактеріальна терапія на сьогодні немислима без застосування антибіотиків. Однак їх широке і не завжди обґрунтоване застосування викликало розвиток антибіотикорезистентності у бактерій - явище, яке має велике соціально-економічне значення і створює реальну загрозу здоров'ю пацієнтів. Формування антибіотикорезистентних штамів мікроорганізмів спонукає клініцистів для подолання цього явища вдаватися до призначення антибіотиків другого і третього ряду, які мають вищу вартість і менш сприятливий профіль безпеки. У зв'язку з цим актуальність вибору раціональної антибіотикотерапії стає визначальним фактором при призначенні антибактеріального препарату і стосується усіх напрямків практичної охорони здоров'я, включаючи загальну терапію, пульмонологію, фтизіатрію, педіатрію, гастроентерологію, всі розділи хірургії, оториноларингологію, гінекологію тощо. У клінічній практиці серед найбільш застосовуваних антибіотиків залишаються три основні класи антимікробних препаратів: $\beta$-лактами, фторхінолони і макроліди. Остання група препаратів має виключне значення при лікуванні інфекцій дихальних шляхів і ЛОР-органів, інфекції, спричиненої Helicobacter pylori (H. pylori), мікобактеріозів та інфекцій органів малого таза, м'яких тканин і шкіри, хламідійної та уроплазмової інвазії.

Макроліди, проявляючи високу антибактеріальну активність відносно грампозитивних, грамнегативних та внутрішньоклітинних збудників, мають протизапальну, імуномодулюючу та мукорегулюючу дію, зберігають при цьому незначну частку розвитку антибіотикорезистентності.

Згідно з клінічним протоколом надання медичної допомоги за спеціальністю «Пульмонологія», затвердженим наказом Міністерства охорони здоров'я України від 19.03.2007 р. № 128, госпіталізованим у терапевтичне відділення хворим на негоспітальнупневмонію III групи необхідно проводити комбіновану антибіотикотерапію із застосуванням захищеного амінопеніциліну парентерально чи цефалоспорину II-III покоління у поєднанні з макролідом. Для лікування хворих IV групи, які не мають факторів ризику інфікування Pseudomonas aeruginosa, рекомендують внутрішньовенно вводити захищений амінопеніцилін або цефалоспорин III покоління у поєднанні з макролідом. Для лікування хворих IV групи з наявністю факторів ризику інфікування Pseudomonas aeruginosa необхідно призначати внутрішньовенно антипсевдомонадний цефалоспорин IIIIV покоління (цефтазидим, цефоперазон, цефепім) у поєднанні з аміноглікозидом та левофлоксацином або ципрофлоксацином. Як альтернативну терапію застосовують цефалоспорин, активний щодо синьогнійної палички (цефтазидим, цефоперазон, цефепім), у поєднанні з аміноглікозидом та макролідом.

Застосування макролідів у пацієнтів із легеневою патологією (тяжка нозокомінальна, вентиляторасоційована (ВАП) та позагоспітальна пневмонія), а також при септичних станах підтвердило їх

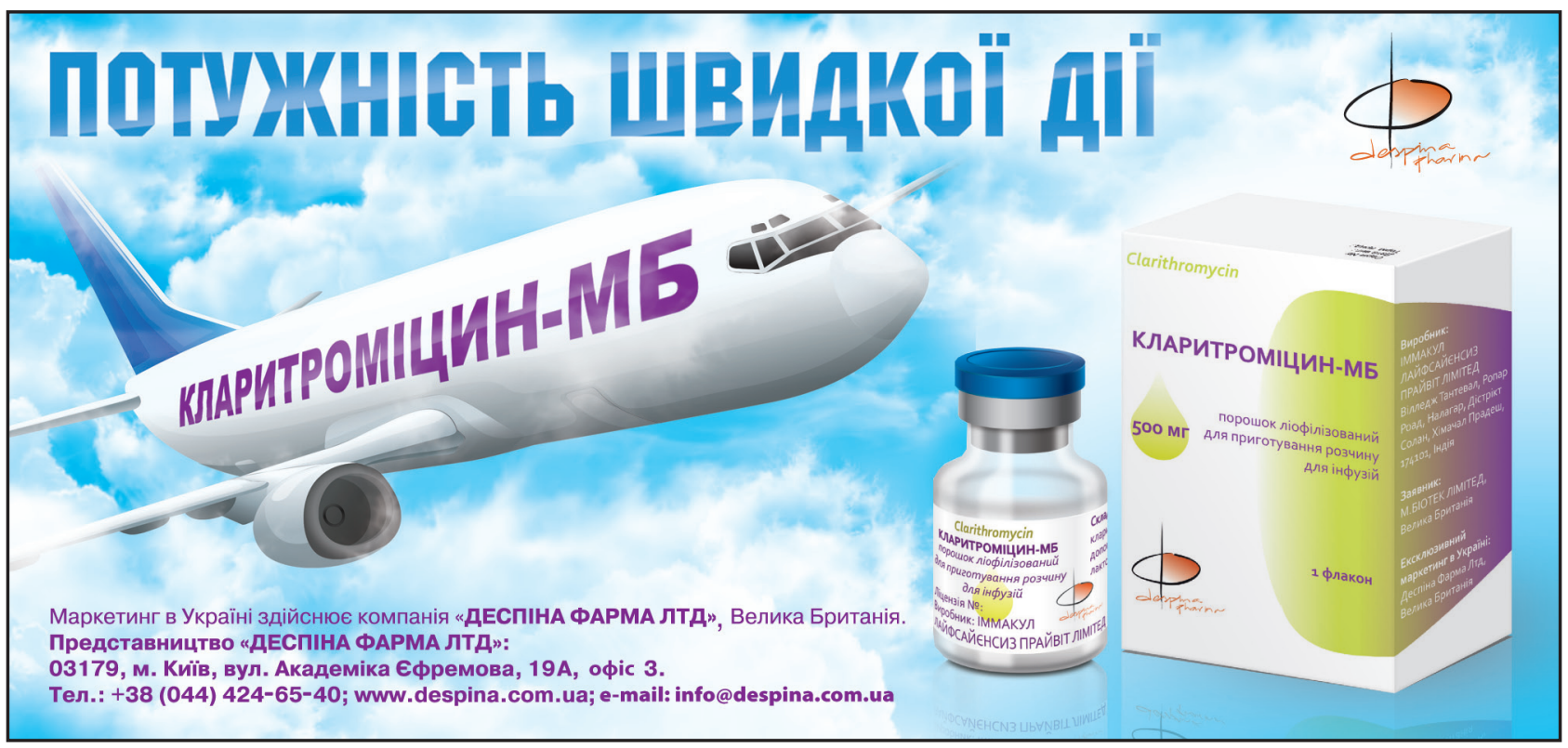



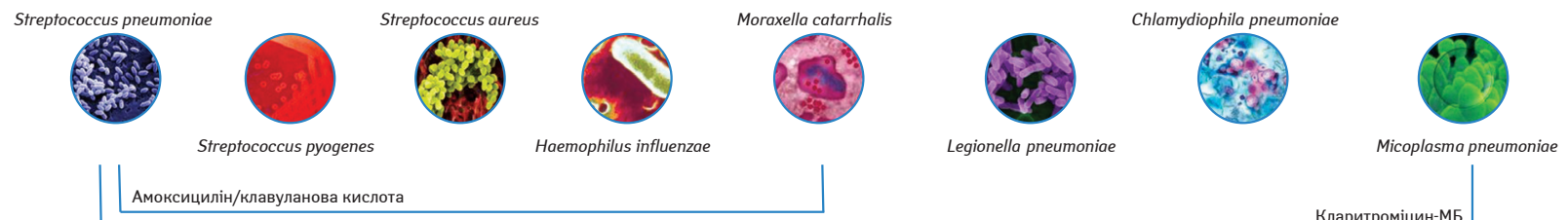

Кларитроміцин-МБ

Рисунок. Спектр антимікробної дії кларитроміцину

високу ефективність. Особливо це стосується їх здатності пришвидшувати одужання хворих із ВАП та вдвічі вищу ймовірність відлучення їх від штучної вентиляції легень, а у хворих із септичними станами - знизити смертність від різних причин (Giamarellos-Bourboulis E.J. etal., 2008; Spyridaki A. etal., 2012). Така здатність не є зайвою: проблема лікування хворих на сепсис досить актуальна, оскільки це загрозливий стан із високою летальністю - 35-50\% (Heron M., 2007).

Одним із представників цієї групи препаратів є кларитроміцин, схвалений до застосування у 1991 р. Препарат випускають у формі таблеток для перорального застосування іпорошкудляприготування розчину для інфузій.

Структурно кларитроміцин - напівсинтетичний препарат, отриманий у результаті хімічної модифікації еритроміцину. Його протимікробна дія зумовлена здатністю блокувати синтез білка мікробною клітиною. Це зумовлюєдосить широкий спектр активностіпрепарату: кокова група бактерій, лістерії, дифтерійна паличка, нейсерія гонореї та менінгіту, спірохети, бруцели та внутрішньоклітинні організми (хламідії, мікоплазма, уреаплазма, легіонели, H. pylori). Завдяки певним хімічним трансформаціям спектр антибактеріальної активності кларитроміцину вдалося поліпшити, створивши властивості, характерні лише для нього. До них належать підвищена активність проти Haemophilus influenzae; найвища активність серед усіх макролідів відносно H. pylori; здатність діяти наатипові мікобактерії (Mycobacterium avium та ін.), що викликають опортуністичні інфекції при СНІДі. Серед оригінальних властивостей препарату - здатність активно проникати та накопичуватись утканинах, здебільшогоу легенях, бронхіальному секреті та інших рідинах, мигдаликах та передміхуровій залозі, а також у товщі біоплівок і внутрішньоклітинно. Здатність впливати на мікроорганізми, що розвиваються внутрішньоклітинно у товщі біоплівок, робитьпрепарат незамінним при лікуванні ряду тяжкихускладнень інфекційного походження, спричиненихзастосуванням медичних пристроїв довготривалої дії (кардіостимуляторів, внутрішньосерцевих електродів, портів для внутрішньовенного введення рідин, катетерів для діалізу тощо). Ці характеристики виявилися важливими для досягнення ерадикації при лікуванні виразки шлунка, спричиненої H. pylori, і патології ЛОР-органів, де хронізація процесу у $57,5 \%$ пацієнтів зумовлена утворенням біоплівки асоціаціями Haemophilus influenzae, Streptococcus pneumoniae i Moraxella catarrhalis (Calò L. etal., 2011). Спектр антимікробної дії кларитроміцинупоказано на рисунку.

\section{Клінічне застосування}

За необхідності парентерального застосування надійним інструментом $€$ препарат Кларитроміцин-МБ (р.п. МОЗ України № UA/17409/01/01). Впровадження у клінічну практику препарату з парентеральним шляхом введення дозволило широко застосовувати його ухворихіз тяжким перебігом легеневої інфекції, ВАПітяжким сепсисом (Giamarellos-Bourboulis E.J. etal., 2008). Однакефективність препаратузумовленане лише його антибактеріальноюдією. Він одночасно виявляє ознаки імуномодулюючого та протизапального препарату, перш за все за рахунок підвищення здатності фагоцитів до хемотаксису. Протизапальний ефект є наслідком зниження активності циклооксигенази і ліпооксигенази клітин. Останнім часом стало відомо і про пригнічення медіаторного ланцюга прозапальних цитокінів, таких як фактор некрозу пухлини-а, інтерлейкін-6 (Gogos C.A. et al., 2000), що значною мірою сприяло підвищенню ефективності лікування при сепсисі з мультиорганною недостатністю і тяжкою формою ВАП (Giamarellos-Bourboulis E.J. et al., 2008).

Кларитроміцин входить до складу трикомпонентної ступінчастої терапії як основний антимікробний препарат (Chang J.Y. et al., 2017). Завдяки впровадженню в схему лікування кларитроміцину вдалося досягти рівня ерадикації H. pylori >80,0\%. Це стало підставою на Маастрихтській конференції рекомендувати цю схему лікування (Malfertheiner P. et al., 2012) як терапію першої лінії, яка в подальшо- му була прийнята практично всіма світовими погоджувальними конференціями.

Наявність на фармацевтичному ринку України кларитроміцину у формі для парентерального застосування дає додаткові можливості лікарю у лікуванні хворих. Це особливо важливо для складних пацієнтів, які поступають у стаціонарне відділення з патологією дихальних шляхів, ЛОР-органів та мають ризик наявності атипічних та резистентних збудників.

\section{Список використаної літератури}

Міністерство охорони здоров'я України (2007) Наказ М03 України від 19.03.2007 р. № 128 «Про затвердження клінічних протоколів надання медичної допомоги за спеціальністю «Пульмонологія» (http://www.ifp.kiev.ua/doc/staff/MOZ128-19032007.pdf).

Calò L., Passàli G.C, Galli J. (2011) Role of biofilms in chronic inflammatory diseases of the upper airways. Adv. Otorhinolaryngol., 72: 93-96. doi: 10.1159/000324622.

Chang J.Y., Shim K.-N., Tae Ch.H. et al. (2017) Triple therapy versus sequential therapy for the first-line Helicobacter pylori eradication. BMC Gastroenterol., 17: 16.

Giamarellos-Bourboulis E.J., Pechère J.C., Routsi C. et al. (2008) Effect of clarithromycin in patients with sepsis and ventilator-associated pneumonia. Clin. Infect. Dis., 46(8): 1157-1164. doi: 10.1086/529439.

Gogos C.A., Drosou E., Bassaris H.P., Skoutelis A. (2000) Pro- versus anti-inflammatory cytokine profile in patients with severe sepsis: a marker for prognosis and future therapeutic options. J. Infect. Dis., 181: 176-180.

Heron M. (2007) Deaths: leading causes for 2004. Natl. Vital. Stat. Rep., 56(5): $1-95$.

Malfertheiner P., Megraud F., O'Morain C.A. et al.; European Helicobacter Study Group (2012) Management of Helicobacter pylori infection - the Maastricht IV/ Florence Consensus Report. Gut, 61(5): 646-664. doi: 10.1136/gutinl-2012-302084.

Spyridaki A., Raftogiannis M., Antonopoulou A. et al. (2012) Effect of clarithromycin in inflammatory markers of patients with ventilator-associated pneumonia and sepsis caused by Gram-negative bacteria: results from a randomized clinical study. Antimicrob. Agents Chemother., 56(7): 3819-3825. doi: 10.1128/AAC.05798-11.

\section{Кларитромицин - надежная антибактериальная защита, проверенная временем}

\section{А.И. Осадчий}

Резюме. В статье рассмотрена общая характеристика группы антибактериальных препаратов, относящихся к макролидам. Определены преимущества и особенности клинического применения кларитромицина и его роль в лечении легочной, ЛОР-патологии и достижении эрадикации при инфицировании Helicobacter pylori, вентиляторассоциированной, нозокоминальной и негоспитальной пневмонии, а также при септических состояниях. Проанализирована целесообразность применения формыпрепаратадляпарентеральноговведения в лечении пациентов с тяжелой инфекцией дыхательных путей.

Ключевые слова: пневмония, макролиды, кларитромицин, Helicobacter pylori, эрадикация.

\section{Clarithromycin - an antibacterial defense proven by time}

\section{O.I. Osadchy}

Summary. The general characteristics of a group of antibacterial drugs related to macrolides are considered. The advantages and features of clinical use of clarithromycin and its role in the treatment of pneumonia, ENT -pathology, the achievement of eradication of Helicobacter pylori infection and in pulmonary pathology (ventilator associated pneumonia, nosocomial and community-acquired pneumonia), as well as in septic conditions were determined. The feasibility of the use of form of the drug for parenteral administration in the treatment of severe respiratory tract infection was made. Key words: pneumonia, macrolides, clarithromycin, Helicobacter pylori, eradication. 